This is an Author's Accepted Manuscript of an article published in Cambridge Review of International Affairs, Volume 18, Number 1, April 2005, pp.15-30 (copyright Taylor \& Francis), available online at: http://www.tandfonline.com/doi/pdf/10.1080/09557570500059514\#.UvtziKOcYkA

[Note for citations: The pagination below corresponds with the printed version of the article.]

\title{
Security Governance and Networks: New Theoretical Perspectives in Transatlantic Security
}

\author{
Elke Krahmann \\ University of Bristol
}

\begin{abstract}
The end of the Cold War has not only witnessed the rise of new transnational threats such as terrorism, crime, proliferation and civil war; it has also seen the growing role of non-state actors in the provision of security in Europe and North America. Two concepts in particular have been used to describe these transformations: security governance and networks. However, the differences and potential theoretical utility of these two concepts for the study of contemporary security have so far been under-examined. This article seeks to address this gap. It proposes that security governance can help to explain the transformation of Cold War security structures, whereas network analysis is particularly useful for understanding the relations and interactions between public and private actors in the making and implementation of national and international security policies.
\end{abstract}

If the terrorist attacks of 11 September 2001 have demonstrated one fact, it is that the new millennium is not more secure or peaceful than the Cold War era. Moreover, they showed that new security threats are able to directly affect distant and major powers. While the number of interstate wars has been decreasing, nonstate threats of terrorism, transnational crime, arms and ethnic conflicts not only appear to be proliferating, but also can have serious consequences for the life and welfare of individuals around the globe. Governments in Europe and North America have been caught largely unprepared for these developments. Following the end of the Cold War, many states substantially reduced their military budgets and the size of their armed forces. Although there was an awareness of new threats from political and economic instability, and the proliferation of weapons of mass destruction (WMDs), they were previously believed to be of limited impact beyond their respective regions. This assessment was wrong. In a globalising world, the direct and indirect effects of instability and conflict cannot easily be contained. The same openness that allows goods, finance and information to flow around the globe permits the transfer of WMDs, the coordination of international terrorist attacks and the operation of transnational crime. Today many governments within the transatlantic region are attempting to redress their failure to prepare for asymmetric threats by combining their forces through multilateral institutions, drawing on the capabilities of non-state actors, nongovernmental organisations (NGOs) and private military companies and adopting new methods of providing security such as network-centric warfare. 
Two concepts in particular have gained currency in analysing these changes in the nature of contemporary threats and the making and implementation of security policies in the transatlantic region: security governance and networks. However, the differences and relationship between these concepts have so far been under-examined. This article seeks to address this gap. It suggests that while the two phenomena are linked, 'security governance' typically refers to the transformation of security policymaking after the end of the Cold War, whereas 'network' models are primarily concerned with the analysis of the relations and interactions between different types of actors in national and international relations. What follows is an attempt to clarify the differences between these two emerging theories and to outline how each can be employed to enhance our understanding of contemporary security.

\section{The Changing Nature of Transatlantic Security}

Before one can turn to an assessment of the content, differences and potential theoretical utility of security governance and network approaches with regard to the analysis of transatlantic security, it is necessary to examine why we should require new theoretical models in the first place. To make this case, this section examines key changes in the nature of national and international security policymaking which appear to be outside the scope of theoretical models that became prominent under the different and historically contingent empirical conditions of the Cold War. In particular, this section describes three transformations in Europe and North America: the rise of non-state security threats, the proliferation of non-state security actors and the emergence of new forms of coordination. It then proceeds to analyse how these empirical developments challenge traditional conceptions of national and international security and how they have contributed to the rise of security governance and networks as new theoretical lenses.

\section{New Security Threats}

The first and perhaps most important challenge to traditional theorising during the past decade and a half has been the transformation of the threat environment following the end of the Cold War and the dissolution of the Warsaw Pact. This applies in particular to Europe and North America, which are the primary focus of this article, but its consequences can also be observed in the rest of the world. Nonstate threats such as civil war, terrorism and the proliferation of WMDs have replaced the threat from proxy wars, nuclear annihilation or a third world war between the two superpowers and their alliances. Partly, the rise of non-state threats as security concerns is the result of the end of the superpower confrontation and the re-emergence of previous suppressed conflicts in the Third World. And partly it reflects the effects of globalisation and the growing integration of societies. While civil wars have outstripped interstate conflicts as the major cause of casualties for decades, it seems that governments and international organisations in the transatlantic region have become increasingly sensitive to the former. This is because today's global economy contains internal or regional wars that can have immediate and serious consequences for states 
around the world. These consequences can range from the flood of refugees to rising prices for essential commodities such as oil or minerals. Other threats such as global terrorism and transnational crime have been created by the increasing level of international interaction, which has been one of the defining characteristics of globalisation (Held and McGrew 2002, 6).

As academics debated the utility of broadening and deepening the concept of security from military to non-military threats and from states to individuals (Ullman 1983; Walt 1991; Rothschild 1995; Baldwin 1997; Krause and Williams 1997), the threat perception of governments and international organisations in the transatlantic region radically changed following the end of the Cold War and, more recently, following 11 September 2001. The development of threat perception in the United Kingdom is representative of the shift from state to non-state threats in Europe and North America. In 1998, the government of the United Kingdom (UK) stated in its strategic review that the clear confrontation of the Cold War had been replaced by a 'complex mixture of uncertainty and instability' (Ministry of Defence[MoD] 1998, para. 2). It concluded that the foremost threats to the UK in this complex mixture were internal conflicts such as in the former Yugoslavia, followed by rogue regimes, the proliferation of WMDs and asymmetrical threats such as drug trafficking, organised crime, terrorism, environmental degradation and attacks on information technology (MoD 1998, para. 41). A direct attack on the UK homeland by another state was virtually ruled out by the review. Instead, especially after the events of 11 September 2001, the UK government has focused on non-state threats. In its 2003 Defence White Paper, the UK Ministry of Defence concluded: 'There is currently no major conventional threat to Europe, but asymmetric forms of attack, including from international terrorism, pose a very real threat to our homelands' (MoD 2003, 5). Similarly, the French Ministry of Defence has proclaimed that 'the main threat to the survival of the French nation has disappeared, probably for a long time. However, the risks related to proliferation and dispersal of weapons of mass destruction have multiplied and they weigh diffusely and insidiously on our strategic environment. ${ }^{1}$ And the German Ministry of Defence announced in its recent Defence Policy Guidelines, 'At present, and in the foreseeable future, there is no conventional threat to the German territory. ${ }^{2}$ In place of the threat of conventional war which dominated the Cold War era, the new threats faced in the transatlantic region do not challenge the territorial integrity of states, but rather the European and North American 'way of life' (Clarke 1998), including the security of citizens and the stability of their economies. In the new millennium, governments and international organisations in Europe and North America are thus perceiving national and international security progressively in broader and more complex terms than they did during the Cold War.

\section{New Actors}

The second challenge to traditional theoretical conceptions is the proliferation and growing role of non-state actors in national and international security. At the same time as governments and international organisations have shifted their primary

1 See khttp://www.defense.gouv.fr/english/def_natio/index-a.htmll.

2 See Bundesministerium der Verteidigung (2003). 
security concerns from interstate war to asymmetric threats, limited resources, lack of expertise in non-traditional areas of security, and divergent interests among governments have facilitated a growing fragmentation of security policymaking. In addition to states, we can today observe a growing number of international institutions and private actors, ranging from non-governmental organisations to private security companies, engaged in security. These actors do not only influence the decision-making process with regard to national and international security concerns; they are also progressively involved in the implementation of public and private security policies.

This is not to argue that states are in the process of being replaced by non-state actors in contemporary security. National governments remain key players as the members of international organisations, NGO donors and employers of private military companies. In fact, it can be argued that the growing role of non-state actors has, to some degree, been the result of governmental policies designed to deal with transnational security issues and to decrease the public burden for the provision of security.

The increasing prevalence of non-state actors in national and international security rests in particular on four factors: number, scope, expertise and resources. The number and scope of international regimes and organisations have grown significantly since the end of the Cold War, which had created obstacles to cooperation. New international regimes include among others the Chemical Weapons Convention; the Comprehensive Nuclear Test-Ban Treaty; and the Convention on the Prohibition of the Use, Stockpiling, Production and Transfer of Anti-Personnel Mines and their Destruction (SIPRI 2003, 764-88). Moreover, the membership and functions of existing multilateral organisations such as NATO, the European Union and the Organisation for Security and Cooperation in Europe (OSCE) have been increasing. Similarly, there has been a proliferation of NGOs engaged in the provision of security, including conflict management, refugee resettlement and humanitarian aid (Minear et al. 2000; Gordenker and Weiss 1996). The emergence of a private military service industry can be viewed as the latest outcome of the progressive fragmentation of security policymaking among state and non-state actors in the post-Cold War era (Edmonds 1998; Fredland and Kendry 1998). It is illustrated by the progressive use of private military companies in the recent intervention in Iraq. According to Deborah Avant $(2004,153)$, the ratio of private military contractors to soldiers has increased from one in fifty during the first Gulf War in 1991 to one in ten during Operation Iraqi Freedom. As governments come under increasing strain due to the growing number and complexity of contemporary security threats and due to the rising cost of national and international defence, non-state actors can offer additional resources and expertise. Moreover, multilateral institutions allow nation-states to address transnational security threats that otherwise appear to be out of their reach.

\section{New Forms of Coordination}

A third challenge to theorising in security studies has been rise of networked modes of coordination among new security threats and among the multiplicity of state and non-state actors that seek to address them. The 'dark networks' (Raab and Milward 2003) that define contemporary security threats such as 
transnational terrorism, global crime and weapons proliferation are not only able to coordinate the resources and actions of criminal actors across national boundaries, but are also particularly suited for evading national defence mechanisms developed during an era that was focused on superpower conflict (Williams 1998, 156; Kenney 2005, 70; Arquilla and Ronfeldt 2001b, 1).

However, the proliferation of networked forms of coordination is not only characteristic of post-Cold-War security threats. In order to effectively respond to these new security challenges, national and international security providers are increasingly employing networks themselves. This shift towards networked modes of coordination ranges from the internal restructuring of government agencies to the creation of formal and informal linkages among public and private actors. The US military, for instance, has developed the doctrine of 'networkcentric warfare', which seeks to use advances in information technology to create direct linkages among military units, thus increasing the speed of command and enabling self-synchronising actions (Cebrowski and Garstka 1998). Other networks have been developing among public and private actors within and among nation-states. Thus William Waugh and Richard Sylves argue that the aftermath of the September 11 terrorist attacks was effectively managed through a network of US agencies, private arms, NGOs and private volunteers (Waugh and Sylves 2002, 148). And in Europe there have been numerous efforts to establish collaborative networks among the national armed forces of EU member states and to institutionalise formal and informal interfaces between international organisations and non-governmental actors operating in conflict regions (Borchert and Rummel 2004). Even globally, there appears to be increasing evidence for the emergence of multilateral inter-governmental and non-governmental networks dealing with issues such as money laundering, freezing terrorist assets and sharing vital information (Slaughter 2004, 159).

\section{Theoretical Challenges}

The transformation of national and international security in Europe and North America has been widely recognised (Rosenau and Czempiel 1992; Pugh 2002; Duffield 2001). However, international relations theory is still in the process of coming to grips with the changes outlined above. In particular, theorising about national and international security has to respond to two challenges. The first regards the underlying premises of key theoretical approaches in security studies, such as neorealism, regime theory and security communities. Specifically, contrary to the empirical observations presented in the preceding sections, these theories are based on the assumption that states are the primary source of insecurity to each other and that they are also the sole actors worthy of consideration that provide for national and international security. Thus, similarly to neorealism (Waltz 1979), the analysis of security regimes has typically been placed within the context of a 'security dilemma' among states (Jervis 1982, 358; Stein 1982, 300). Moreover, even the study of security communities, which suggests that 'because of shared democratic norms and identities ... [ the members of the Atlantic Alliance] did not perceive each other as threats with the end of the Cold War'(Williams and Neumann 2000, 358; also Adler and Barnett 1998, 47), appears to imply that, in the absence of these conditions, states within the 
transatlantic region would view each other as security threats. In addition, all three theoretical approaches are based on the assumption that national and international security is mostly a result of the relations among states-even if, in the case of security communities, a common identity and trust might also be forged through non-governmental contacts (Adler and Barnett 1998, 38).

What is crucial about the discrepancies between these core assumptions and the post-Cold-War security environment in the transatlantic region is not so much the question whether the discrepancies invalidate these theories. More important is that these assumptions impede the theoretical exploration of alternative conditions and their implications for contemporary security. They have directed the above theories to focus on the question of how states can coexist and cooperate peacefully given the threat that they pose to each other (Hasenclever et al. 1996, 177), whereas the theoretical examination of how security would be provided within a system that is predominantly characterised by non-state security threats, multiple public and private security providers, and networked modes of coordination has been neglected.

The second challenge involves the emergence of new questions that are not sufficiently addressed by existing theoretical approaches, such as: What are the consequences of the fragmentation of security policymaking among state and non-state actors for policies, their implementation and their effect on the level of security' Who dominates contemporary security governance arrangements and why' And what are the conditions for the effective and efficient functioning of networked modes of coordination in security'

In response to these challenges, two theoretical frameworks have gained increasing currency among scholars of national and international security: security governance and network analysis (Hanggi 2003; Kirchner 2003; Krahmann 2003b; Raab and Milward 2003; Dillon and Reid 2001; Arquilla and Ronfeldt 2001a). The following sections examine how these two approaches may help to answer these questions and thus improve our understanding of contemporary national and international security.

\section{Security Governance and Networks: Similarities and Differences}

The proposition that security governance and network analysis might be suitable approaches for answering the questions raised above rests on their ability to model the transformations of national and international security policies in Europe and North America. Specifically, both approaches are gaining prominence because they permit an analysis of security policymaking that includes state and non-state actors linked through a mixture of hierarchical and non-hierarchical modes of cooperation. However, the respective theoretical utility of these two approaches, their differences and their relationship have so far been little explored. These tasks are particularly important because of the similarities between the two concepts.

In terms of definition, security governance has been related to the emergence 'structures and processes which enable a set of public and private actors to coordinate their interdependent needs and interests through the making and implementation of binding policy decisions in the absence of a central political authority' (Krahmann 2003b, 11). Whereas networks in security policy have been 
linked to the fact that 'power is migrating to non-state actors, because they are able to organise into multi-organisational networks ... more readily than can traditional, hierarchical, state actors' (Arquilla and Ronfeldt 2001b, 1). Both concepts thus appear to refer to the same phenomena: security policymaking arrangements and processes in which state and non-state actors increasingly cooperate through horizontal as well as hierarchical relationships among each other.

The differences between these two concepts only become apparent in a closer reading of the existing literature on global and security governance and networks in contemporary security policymaking. It can thus be argued that global and security governance has mainly been concerned with the transformation of security policymaking, whereas the notion of networks has been predominantly applied to understanding the relations and interactions within and between public and private organisations at different levels. At the same time, the rise of security governance and networks appears to be connected in that the fragmented governance arrangements facilitates, or perhaps even requires, the adoption of networked forms of coordination among state and non-state actors.

In addition, it can be suggested that governance and network analysis as theoretical frameworks rather than descriptive terms have been concerned with distinct, but overlapping, sets of questions. The literature on global and security governance largely seeks to describe and analyse historical and institutional change in international relations and its consequences. David Held and Anthony McGrew $(2002,1)$ thus contend, 'Any discussion of global governance must start with an understanding of the changing fabric of international society.' Similarly, Martin Hewson and Timothy J. Sinclair $(1999,3)$ argue that 'the question of global change, its sources and its implications, [is] the pre-eminent issue in international relations theorising ... [G]lobal governance theory has emerged as a key vantage point on this central question of our times'.

The changes that have been observed in the governance literature are to some degree based on the three transformations outlined in this article, but they also include shifts in the influence of public and private actors, the proliferation of new institutions and the development of new policies as consequences of the fragmentation of authority among a growing range of actors. In addition, many studies are concerned with the practical problems and normative implications arising from the emergence of global and security governance, ranging from questions of effectiveness and efficiency to the lack of democratic accountability and legitimacy (Government and Opposition 2004).

Network analysis, on the other hand, has primarily been concerned with questions such as: Who are the most powerful or central actors within particular governance arrangements' How do relations between actors influence their interactions' How are network structures related to particular outcomes' According to Peter Klerks $(2002,53)$, ' $[$ s] ocial network mapping can show what material resources someone can mobilize and which information he has access to. It can also introduce dynamics into the rigid and 'frozen' understanding of social structures.' Network analysis has been applied both to the analysis of threats and to policymaking. In addition, network, like governance, analysis investigates the conditions under which policy outcomes meet normative and efficiency criteria. Thus Anthony Dekker (2002, 94; see also Raab and Milward 2003, 414) argues in his study of networks within the military that the 'most important goal of social 
network analysis is to make recommendations to improve communication and workflow in an organisation' based on its insights into the relationships between actors and their impact on information or coordination processes. It is here that the congruence between the analysis of global and security governance and networks is perhaps strongest.

In order to distinguish the two approaches, their respective scope and hypotheses, the following sections propose that the concept of security governance might best be employed as a theory for the explanation of the transformation from 'government' to 'governance' and the possible systemic consequences of this development for national and international security. Network approaches appear to offer valuable insights into the structure and function of the multiple, diverse and frequently overlapping control and coordination arrangements that together make up global and security governance (Rosenau 1995, 16). At the same time, insights from both explanatory models contribute to the normative assessment of the shift from government to governance and different types of networked coordination.

\section{Security Governance}

So far research on global and security governance has largely taken a descriptiveanalytical approach to understanding the growing fragmentation of policymaking among states, international organisations and private actors as part of a shift from centralised, state-centric 'government' to fragmented, multilateral 'governance' (Kirchner 2003; Webber et al. 2004). However, an increasing number of demands have been made to formulate insights gathered from empirical studies into theoretical propositions designed to explain the emergence of global and security governance and hypothesise about its implications for international relations in the new millennium. This section outlines how the concept of security governance might be used to theoretically explain the transformation of security and its implications.

While national, regional and global governance have been defined as the fragmentation of political coordination in different dimensions, including geography, function, resource distribution, interests, norms, decision-making and policy implementation (Krahmann 2003c), the concept of security governance applies this definition to the changing structures and processes that characterise national and international security. It suggests, among other aspects, that contemporary security policymaking and implementation are not the exclusive sphere of nation-states, but increasingly extend beyond national borders; that they are structured along functional lines; and that they involve non-state actors such as international institutions, NGOs and private companies.

As a theoretical concept, security governance rests on several premises concerning the nature of contemporary international relations, which are very different from those discussed earlier in this article. The first premise, which is supported by the empirical findings presented in the preceding sections, contends that interstate war has been replaced with non-state and intrastate threats such as terrorism, proliferation of weapons and civil conflicts as the most important source of insecurity in Europe and North America (Thomas 2000, 161-62; Rosenau 1992, 3; Tuathail et al. 1998, 12). The second, related premise is that the 
multiplicity, complexity and internal or transnational nature of contemporary security threats are challenging the ability of sovereign nation-states to ensure the security of their citizens (Arquilla and Ronfeldt 2001b, 1). Since the new threats are able to transgress national boundaries, states within the transatlantic region are increasingly required to cooperate or draw on non-state actors such as international organisations to combat them. This leads to the third premise, which suggests that the state's exclusive provision of national and international security, which characterised Europe and North America during the Cold War, is increasingly being eroded and that the norm of the state monopoly on the legitimate use of force is being replaced by considerations of efficiency and costeffectiveness (Markusen 2003, 473; Pint et al. 2001).

Several interrelated hypotheses might be proposed on the basis of these premises, which can help to explain the emergence of security governance in Europe and North America. The first hypothesis regards the effects of the changing nature of contemporary threats on the provision of security. It proposes that if governments are no longer primarily concerned with threats from other states, but rather are concerned with threats from non-state actors, and if the threat to the existence and territory of the state has been replaced by that to the security of citizens and the stability of the economy, governments not only face the need to cooperate with other state and non-state actors but also are increasingly free to do so. Security governance thus helps to explain the proliferation of transnational cooperation and institutions among both state and non-state actors in the postCold-War era as outlined above.

However, security governance does not imply that this development requires the unifying efforts of a hegemonic power or that it will lead to further integration. Conversely, security governance hypothesises that the decreased threat from interstate war permits cooperation to proceed within more flexible 'coalitions of the willing'. One reason for this development is that in the post-Cold-War era smaller and changeable alliances are no longer perceived as disturbing a precarious balance of power within Europe. Another is that coalitions of the willing are more suited to accommodate the complex and regionally differentiated impact of asymmetric security threats.

Unlike the unifying threat of the Warsaw Pact, the new threats such as terrorism and transnational crime are more likely to affect the security and interests of states in the transatlantic region to different degrees. Coalitions of the willing are able to reflect these differences by allowing cooperation among state and non-state actors in response to specific threats or local crises. Moreover, due to the fragmented and diverse nature of the new security threats, existing alliances and organisations are likely to increasingly develop structures, such as NATO's Combined Joint Task Forces, which permit internal coalitions of the willing, allowing members to cooperate without the direct involvement of others (Bensahel 1999; Stuart 2004).

Third, security governance proposes that the complexity of the new threats, the weakening of the state monopoly on the provision of security and the rise of cost-efficiency as a legitimising mechanism promote geographical and functional specialisation among state and non-state actors in order to reduce the cost of providing national and international security. In particular in Europe, governments thus increasingly recognise the advantages of 'role sharing' through developing specialised military units, which they can contribute to international 
peacekeeping operations (NATO 2002). Other attempts at specialisation include United Nations subcontracting missions to regional organisations or NGOs (Knight 1996).

But how is the emergence of security governance linked to the growth of networked forms of coordination' As has been outlined by Mette Eilstrup Sangiovanni in this issue, networks are particularly suited for accommodating the above developments, for several reasons. First, due to the inclusion and frequent dominance of informal relations, networks are relatively flexible and can adapt comparatively quickly and easily to new actors or demands. While formal institutional linkages require considerable time and resources in order to be established in national law or international regimes, informal relations can be set up instantaneously among actors that have an interest in an exchange or collaboration on a particular security issue. New actors can enter these relations on the basis of their capabilities and open channels of communication. New issues or problems can be responded to by the formation of new networks among affected actors or the transformation of existing networks in order to enlarge their scope or capabilities. Networks are thus especially fitting for coordination among state and non-state actors in complex humanitarian emergencies or intergovernmental cooperation in flexible coalitions of the willing.

Second, with their informal and horizontal relations, networks can stretch more easily than formal hierarchical structures across national boundaries and sovereignties (Keck and Sikkink 1998). Networks are thus particularly adept at addressing transnational security threats and issues such as managing refugee flows and monitoring the proliferation of WMDs.

Third, through decentralisation, networks promote geographical and functional specialisation through subsidiaries, i.e. the making and implementation of policies by those who are affected (Knight 1996, 47). Networks can thereby encourage the development of differentiated solutions for a complex world rather than the imposition of centrally directed, uniform policies. Moreover, networks can foster the use of local knowledge and resources, which benefits the long-term advancement of affected communities. Drawing on local groups, personnel and assets is frequently more cost-efficient than using centralised capabilities.

This is not to suggest that networks are generally more efficient and effective than traditional modes of coordination in national and international security, or to argue that the emergence of networks or security governance occurs without problems. In particular, questions of transparency, accountability and legitimacy in governance and networking are being discussed in a growing range of research (Government and Opposition, 2004; van Kersbergen and van Waarden, 2004).

While the emergence of security governance might contribute to explaining the proliferation of networks as a mode of coordination, and some if its implications, the preceding theoretical model fails to illustrate how coordination proceeds within particular governance arrangements. Network analysis has proposed some answers to this question.

\section{Network Analysis}

Like global and security governance, network analysis began its life as a descriptive-analytic concept rather than a theoretical approach (Dowding 1995). 
Since the 1990s, however, a number of network models has been developed that help to answer key questions such as: Who dominates particular networks and why' How do networks influence the processes and outcomes of formal and informal coordination among different types of actors' And what are the conditions for the effective functioning of networks' Since it is beyond the scope of this article to discuss all of these in detail, ${ }^{4}$ the following will focus primarily on social network approaches that have been applied to national and international security and offer testable hypotheses.

In general, networks have been defined as sets of actors that share an interest in a specific issue area and are linked to each other through stable formal or informal relations (Atkinson and Coleman 1992). In the study of security, network analysis has predominantly been concerned with the linkages among terrorist and criminal networks (Baker and Faulkner 1993; Krebs 2002; Raab and Milward 2003; Williams 2001), the development of network-centric warfare (Cebrowski and Garstka 1998; Dekker 2002) and relations among public and private foreign and security policymakers (Krahmann 2003a). These networks allow for a mixture of linkages ranging from hierarchical to horizontal (Kenis and Schneider 1991, 42) and are based, among other things, on the exchange of information, resources, support or commitments (Raab and Milward 2003, 417; Williams 1998, 155).

The basic premise of all network analyses is that, in addition to the character, beliefs and interests of actors, the relations among a set of actors have a major impact on the ways in which they interact and on the outcomes of these interactions, be they preferences, policies or resource exchanges (Borzel 1998, 258). However, there are multiple ways in which network structures have been defined and measured. Social network analysis has been based on a number of factors, including the strength, number and distribution of the relations among sets of actors or 'nodes'. Depending on the purpose of the network, the strength of these relations can be measured in terms of frequency of contact and communication (van Meter 2002), length of contact and the nature of transactions (Krebs 2002, 44), the character of communication (Klerks 2002, 61), direct contact and joint attendance of meetings (Baker and Faulkner 1993, 847), and institutional linkages and resource dependencies (Krahmann 2003a, 24 '26).

Frequently, the analysis of these measures is based on questioning the actors involved in a network. This not only offers an accurate assessment of the network structure as it is viewed by its members, but also helps to delineate the boundaries of a network, since actors are asked to give complete information about the extent of their linkages with other actors. However, some networks such as transnational crime cartels and the al Qaeda terrorist network can only be mapped through witness accounts in courts or newspaper sources (Krebs 2002, 43; Klerks 2002, 57; Baker and Faulkner 1993, 846). Others 'in particular, networks among governments and international organisations' lend themselves to the analysis of formal and information institutional relations as well as resource dependencies (Krahmann 2003a, 24-26).

Based on the structure of a particular network, social network analyses propose a number of related hypotheses. The first hypothesis is that the centrality or position of a particular actor within a network determines his or her ability to interact with and in'uence the notions of other members. Measures of

4 For an overview of network approaches see van Waarden (1992). 
centrality include degree, i.e. the number of direct links an actor has with other members; betweenness, i.e. the ability of an actor to link to important constituencies; and closeness, i.e. an actor's ability to see what is happening within the network (Krebs 2002, 48; Baker and Faulkner 1993, 846). Social network analysis distinguishes between two main positions: core and periphery. However, there are also distinct positions such as 'gatekeepers' who are able to link different sections of a network (van Meter 2002, 69). The centrality is at once a measure of the power of an actor and his or her vulnerability. Thus, the study of terrorist networks suggests that centrality enhances actors' information and control over a network. However, central actors are more easily identified and targeted (Arquilla and Ronfeldt 2001b, 9). Similarly, in the making of foreign and security policies, central actors can be subject to political pressure from a larger number of actors, yet they can also exert pressure across a wider range (Krahmann 2003a, 39).

The second hypothesis is that the structure of a network plays an important role in shaping processes and outcomes. On the one hand, centralised networks permit efficient coordination and exchange of resources, since most actors are able to contact each other or a central core that distributes information. This is illustrated by the development of network-centric warfare which builds on a combination of networked forms of coordination with advanced computer technology in order to enhance real-time information exchanges among geographically dispersed and functionally differentiated military units (Alberts et al. 2000, 88). Specifically, network-centric warfare enables actors to 'selfsynchronise' (Cebrowski and Garstka 1998) or 'swarm' the enemy simultaneously from different directions (Arquilla and Ronfeldt 2001c, 368).

However, self-synchronisation and swarming rest on a commonality of interests and objectives (Arquilla and Ronfeldt 2001b, 9) which cannot necessarily be assumed beyond intra-organisational networks. In particular, in networks involving different types of actors, for instance armed forces and NGOs, coordination is frequently complicated by differences in values and interests and may therefore require more direct negotiation (Minear et al. 2000). Nevertheless, John Arquilla and David Ronfeldt (2001b, 5) point to instances where inter-organisational self-synchronisation between NGOs and government agencies has been successful, such as in the international campaign to ban landmines.

Decentralised networks, on the other hand, allow transnational terrorist groups to limit information flows in order to protect their members (Krebs 2002, 46); whereas in the making and implementation of security policies they enable localised action and autonomy (Arquilla and Ronfeldt 2001b, 9). Moreover, temporary linkages are created as short cuts in order to overcome the sluggishness of decentralised networks at times of high activity (Krebs 2002, 47).

Finally, 'structural holes' in networks can help to explain why certain interactions and outcomes do not occur (Klerks 2002, 62). In security policymaking, they suggest that coalitions of interest may form among sets of individuals or organisations whereas other coalitions fail to emerge, and how these coalitions help determine policies (Krahmann 2003a, 157). 


\section{Conclusion}

The transformation of the global security environment in the post-Cold-War era has led to a growing demand for new theoretical approaches that reflect the changing nature of contemporary security threats and policies and explore their implications. Security governance and network analysis aim to provide such models. However, so far these two concepts have been primarily used in a descriptive-analytical way, leaving their theoretical potential under-explored. This article has sought to contribute to clarifying this potential. In particular, it has attempted to illustrate why we might need new theoretical approaches for the analysis of contemporary security and how security governance and network analysis might be employed for this purpose. It has argued that security governance seems to be particularly useful for explaining the transformation from the centralised security arrangements that characterised much of the last century towards a more fragmented provision of security involving states, international organisations and a growing range of private actors. Network analysis, on the other hand, offers fruitful insights into the decision-making structures and processes that have emerged among different types of security providers and nonstate actors threatening contemporary security. Moreover, network analysis helps to answer the question of how the relations among these actors shape the outcomes of their coordination with regard both to threats and to the making and implementation of security policies.

However, like a lot of research this exposition raises as many questions as it may answer. In particular, it invites further research into the positive and negative consequences of the emergence of security governance and the proliferation of networks. Are these structures really more efficient and effective than those which dominated during the Cold War era' What makes them effective' Moreover, are they transparent, accountable and legitimate' A growing range of research is being conducted, especially on the normative consequences of the shift from government to governance, as the 2004 special issue of Government and Opposition attests. However, we will need to apply these approaches to a broader range of empirical studies that, in the case of network analysis, involve not only terrorism and transnational crime but also the growing transnational networks among state and non-state actors engaged in the provision of security in order to find some answers.

\section{References}

Adler, E. and Barnett, M. (1998) 'A Framework for the Study of Security Communities', in: E. Adler and M. Barnett (Eds), Security Communities (Cambridge, Cambridge University Press).

Alberts, D.S., Garstka, J.J. and Stein, F.P. (2000) Network Centric Warfare. Developing and Leveraging Information Superiority, 2nd rev. edn (Washington, CCRP).

Arquilla, J. and Ronfeldt, D.F. (Eds) (2001a) Networks and Netwars. The Future of Terror, Crime, and Militancy (Santa Monica, CA, Rand).

Arquilla, J. and Ronfeldt, D.F. (2001b) 'The Advent of Netwar (revisited)', in: J. Arquilla and D.F. Ronfeldt (Eds), Networks and Netwars. The Future of Terror, Crime, and Militancy (Santa Monica, CA, Rand).

Arquilla, J. and Ronfeldt, D.F. (2001c) 'Afterword (September 2001): The Sharpening Fight for the Future', in: J. Arquilla and D.F. Ronfeldt (Eds), Networks and Netwars. The Future of Terror, Crime, and Militancy (Santa Monica, CA, Rand). 
Atkinson, M.M. and Coleman, W.D. (1992) 'Policy Networks, Policy Communities and the Problems of Governance', Governance, 5(2), pp. 154-80.

Avant, D. (2004) 'The Privatization of Security and Change in the Control of Force', International Studies Perspectives, 5(2), pp. 153-57.

Baker, W.E. and Faulkner, R.R. (1993) 'The Social Organisation of Conspiracy: Illegal Networks in the Heavy Electrical Equipment Industry', American Sociological Review, 58(6), pp. 837-60.

Baldwin, D.A. (1997) 'The Concept of Security', Review of International Studies, 23(1), pp. 5-29.

Bensahel, N. (1999) 'Separable but Not Separate Forces: NATO's Development of the Combined Joint Task Force', European Security, 8(2), pp. 52-72.

Borzel, T.A. (1998) 'Organising Babylon'On the Different Conceptions of Policy Networks', Public Administration, 76(2), pp. 253-73.

Borchert, H. and Rummel, R. (2004) 'Von segmentierter zu vernetzter Sicherheitspolitik in der EU-25', Osterreichische Militarzeitschrift, 42(3), pp. 259-68.

Bundesministerium der Verteidigung (2003) Defence Policy Guidelines (Berlin, Bundesministerium der Verteidigung), khttp:/ /www.bmvg.de/misc/pdf/sicherheit/ 030521_VPR-english.pdfl.

Cebrowski, A.K. and Garstka, J.J. (1998) 'Networks Centric Warfare: Its Origins and Future', Proceedings, 124(1/1, 139), khttp:/ /www.usni.org/proceedings/Articles98/ PROcebrowski.html.

Clarke, M. (1998) 'Memorandum Submitted on the Foreign and Security Policy Aspects of the Strategic Defence Review', in: Eighth Report: The Strategic Defence Review, Volume II'Minutes of Evidence \& Memoranda (London: The Stationery Of'ce), pp. 138- II, $\mathrm{HC}$.

Dekker, A. (2002) 'Applying Social Network Analysis Concepts to Military C4ISR Architectures', Connections, 24(3), pp. 93-103.

Dillon, M. and Reid, J. (2001) 'Global Liberal Governance: Biopolitics, Security and War', Millennium, 30(1), pp. 41-66.

Dowding, K. (1995) 'Model or Metaphor' A Critical Review of the Policy Network Approach', Political Studies, 43(7), pp. 136-58.

Duf'eld, M. (2001) Global Governance and the New Wars. The Merging of Development and Security (London, Zed Books).

Edmonds, M. (1998) 'Defense Privatisation: From State Enterprise to Commercialism', Cambridge Review of International Affairs, 13(1), pp. 114-29.

Fredland, E. and Kendry, A. (1998) 'The Privatisation of Military Force: Economic Virtues, Vices and Government Responsibility', Cambridge Review of International Affairs, 13(1), pp. 147-64.

Gordenker, L. and Weiss, T.G. (1996) 'Pluralizing Global Governance: Analytical Approaches and Dimensions', in: NGOs, the UN, and Global Governance (London, Lynne Rienner).

Government and Opposition (2004) 'Special Issue on Legitimacy and Global Governance', 39(2).

Hanggi, H. (2003) 'Making Sense of Security Sector Governance', in: H. Hanggi and T.H. Winkler (Eds), Challenges of Security Reform (Munich, LIT Verlag).

Hasenclever, A., Mayer, P. and Rittberger, V. (1996) 'Interests, Power, Knowledge: The Study of International Regimes', Mershon International Studies Review, 40(2), pp. 177-228.

Held, D. and McGrew, A. (2002) 'Introduction', in: D. Held and A. McGrew (Eds), Governing Globalization: Power, Authority and Global Governance (Cambridge, Polity Press), pp. 1-21.

Hewson, M. and Sinclair, T.J. (1999) 'The Emergence of Global Governance Theory', in: M. Hewson and T.J. Sinclari (Eds), Approaches to Global Governance Theory (Albany, State University of New York Press).

Jervis, R. (1982) 'Security Regimes', International Oranisation, 36(2), pp. 357-78.

Keck, M. and Sikkink, K. (1998) Activists beyond Borders: Transnational Advocacy Networks in World Politics (Ithaca, NY, Cornell University Press).

Kenis, P. and Schneider, V. (1991) 'Policy Networks and Policy Analysis: Scrutinizing a New Analytical Toolbox', in: B. Marin and R. Mayntz (Eds), Policy Networks. Empirical Evidence and Theoretical Considerations (Frankfurt, Campus). 
Kenney, M. (2005) 'Drug Traffickers, Terrorist Networks and Ill-fated Government Strategies', in: E. Krahmann (Ed.), New Threats and New Actors in International Security (New York, Palgrave).

Kirchner, E.J. (2003) European Security Trends (Miami, Miami European Union Center).

Klerks, P. (2002) 'The Network Paradigm Applied to Criminal Organisations: Theoretical Nitpicking or a Relevant Doctrine for Investigators' Recent Developments in the Netherlands', Connections, 24(3), pp. 53-65.

Knight, W.A. (1996) 'Towards a Subsidiarity Model for Peacemaking and Preventive Diplomacy: Making Chapter VIII of the UN Charter Operational', Third World Quarterly, 17(1), pp. 31-52.

Krahmann, E. (2003a) Multilevel Networks in European Foreign Policy (Aldershot, Ashgate).

Krahmann, E. (2003b) 'Conceptualizing Security Governance', Cooperation and Con'ict, 38(1), pp. 5-26.

Krahmann, E. (2003c) 'National, Regional and Global Governance: One Phenomenon or Many', Global Governance, 9(3), pp. 323-46.

Krause, K. and Williams, M.C. (Eds) (1997) Critical Security Studies. Concepts and Cases (Minneapolis, University of Minnesota Press).

Krebs, V.E. (2002) 'Mapping Terrorist Networks', Connections, 24(3), pp. 43-52.

Markusen, A.R. (2003) 'The Case against Privatizing National Security', Governance, 16(4), pp. 471-501.

Minear, L., van Baarda, T. and Sommers, M. (2000) NATO and Humanitarian Action in the Kosovo Crisis (Providence, Thomas J. Watson, Jr Institute for International Studies).

Ministry of Defence (1998) Strategic Defence Review (London: The Stationery Office).

Ministry of Defence (2003) Delivering Security in a Changing World. Defence White Paper (London: The Stationery Office).

NATO (2002) Final Communique, Ministerial Meeting of the Defence Planning Committee and the Nuclear Planning Group, Brussels, 6 June khttp://www.nato.int/docu/pr/ 2002/p02-071e.html.

Pint, E.M., Bondanella, J.R., Cave, J., Hart, R. and Keyer, D. (2001) Public-Private Partnerships. Background Papers for the U.S.' U.K. Conference on Military Installation Assets, Operations, and Services (Santa Monica, CA, Rand).

Pugh, M. (2002) 'Maintaining Peace and Security', in: D. Held and A. McGrew (Eds), Governing Globalisation: Power, Authority and Global Governance (Cambridge, Polity Press).

Raab, J. and Milward, H.B. (2003) 'Dark Networks as Problems', Journal of Public Administration Research and Theory, 13(4), pp. 413-39.

Rosenau, J.N. (1992) 'Governance, Order and Change in World Politics', in: J.N. Rosenau and E.-O. Czempiel (Eds), Governance Without Government (Cambridge, Cambridge University Press).

Rosenau, J.N. (1995) 'Governance in the Twenty-first Century', Global Governance, 1(1), pp. 13-43.

Rosenau, J.N. and Czempiel, E.O. (Eds) (1992) Governance without Government: Order and Change in World Politics (Cambridge, Cambridge University Press).

Rothschild, E. (1995) 'What is Security', Daedalus, 124(3), pp. 53-98.

SIPRI (2003) SIPRI Yearbook 2003 (Oxford, Oxford University Press).

Slaughter, A.-M. (2004) 'Disaggregated Sovereignty: Towards the Public Accountability of Global Government Networks', Government and Opposition, 39(2), pp. 159-90.

Stein, A.A. (1982) 'Coordination and Collaboration: Regimes in an Anarchic World', International Organisation, 36(2), pp. 299-324.

Stuart, D.T. (2004) 'NATO and the Wider World: From Regional Collective Defence to Global Coalitions of the Willing', Australian Journal of International Affairs, 58(1), pp. 33-46.

Thomas, C. (2000) Global Governance, Development and Human Security (London, Pluto).

Tuathail, G.O., Herod, A. and Roberts, S.M. (1998) 'Negotiating Unruly Problematics', in:

A. Herod, G.O Tuathail and S.M. Roberts (Eds), An Unruly World' Globalisation, Governance and Geography (London, Routledge).

Ullman, R.H. (1983) 'Rede'ning Security', International Security, 8(1), pp. 129-53.

Van Kersbergen, K. and van Waarden, F. (2004) 'Governance' as a Bridge Between the Disciplines: Cross-disciplinary Inspiration Regarding Shifts in Governance and 
Problems of Governability, Accountability and Legitimacy', European Journal of Political Research, 43(2), pp. 143-71.

Van Meter, K.M. (2002) 'Terrorists/Liberators: Researching and Dealing with Adversary Social Networks', Connections, 24(3), pp. 66 -78.

Van Waarden, F. (1992) 'Dimensions and Types of Policy Networks', European Journal of Political Research, 21(1-2), pp. 29-52.

Walt, S.M. (1991) 'The Renaissance of Security Studies', International Studies Quarterly, 35(2), pp. 211-39.

Waltz, K. (1979) Theory of International Politics (Reading, MA, Addison-Wesley).

Waugh, W.L., Jr and Sylves, R.T. (2002) 'Organizing the War on Terrorism', Public Administration Review, 62, pp. 145-53.

Webber, M., Croft, S., Krahmann, E., Howorth, J. and Terriff, T. (2004) 'The Governance of European Security', Review of International Studies, 30(1), pp. 3-26.

Williams, M.C. and Neumann, I.B. (2000) 'From Alliance of Security Community: NATO Russia, and the Powers of Identity', Millennium, 29(2), pp. 357-87.

Williams, P. (1998) 'The Nature of Drug-Trafficking Networks', Current History, 97(618), pp. 154-59.

Williams, P. (2001) 'Transnational Criminal Networks', in: J. Arquilla and D.F. Ronfeldt (Eds), Networks and Netwars. The Future of Terror, Crime, and Militancy (Santa Monica, CA, Rand). 